\title{
Evaluation of Some Ecute Phase Proteins, Cytokines and Hepcidin Levels in Naturally Infected Saanen Goats with Paratuberculosis
}

\author{
Doğal Enfekte Paratüberküloz̧isli Saanen Keçilerinde Baz̨ Akut Faz Proteinleri, Sitokinler ve Hepsidin \\ Düzeylerinin Değerlendirilmesi
}

\section{Necmettin Sarp SEVGÍSUNAR ${ }^{1}$, Şima ŞAHİNDURAN ${ }^{*}$}

${ }^{1}$ Burdur Mehmet Akif Ersoy University, Faculty of Veterinary Medicine, Department of Internal Medicine, Burdur, Turkey

\begin{abstract}
Johne's Disease or paratuberculosis is a mycobacterial infection of ruminants and has a global economical impact. Mycobacterium avium subsp. paratuberculosis is the cause of this disease. It reduces milk production, cause chronic weight loss leading death and major losses. Acute phase reactions are defined as minimum $25 \%$ increase or decrease in serum concentrations of acute phase proteins which are triggered by pro or antiinflammatory cytokines released from various cells or tissues. The aim of the study was to investigate the effect of Mycobacterium avium subsp paratuberculosis on blood parameters, some acute phase proteins, cytokines and hepcidin in naturally infected goats with paratuberculosis. In this study, total 45 Saanen goats aged 2-5 years from both sex were used as animal material. Study group were included 35 and control group were included 10 animal for evaluation. Complete blood counts were performed on blood taken from all animals. Also interleukin 6, interleukin 10, serum amyloid A, haptoglobin, fibrinogen, and hepcidin levels were evaluated from serum samples. As a result, interleukin $6(\mathrm{p}<0.01)$, interleukin $10(p<0.01)$ serum amyloid A $(p<0.001)$, haptoglobin $(p<0.001)$, fibrinogen $(p<0.05)$, and hepcidin $(p<0.05)$ differences between groups were statistically important and they can be used to support the diagnosis of paratuberculosis.
\end{abstract}

Keywords: Acute phase proteins, Cytokine, Hepcidin, Paratuberculosis, Saanen goat.

Öz: Johne's hastalığı veya paratüberkülozis, ruminantların mikobakteriyel bir hastalığı olup dünya çapında ekonomik kayıplara yol açmaktadır. Hastalığa neden olan etken Mycobacterium avium subsp. paratuberculosis'tir. Süt veriminde azalma, kronik kilo kaybı ve ölümlere neden olmaktadır. Akut faz reaksiyonları, akut faz proteinlerinin hastalık sırasında çeşitli hücre ve dokular tarafindan salgilanan pro veya antienflamatuar sitokinlerin stimulasyonu sonucunda serum konsantrasyonunda en az \% 25 değişim göstermesi şeklinde tanımlanmıştır. Çalşmanın amacı doğal olarak enfekte olmuş paratüberkülozisli keçilerde, Mycobacterium avium subsp. paratuberculosis etkeninin hayvanların kan parametreleri ve bazı akut faz proteinleri ile sitokinler ve hepsidin üzerindeki etkisini araştırmaktı. Çalışmanın hayvan materyalini, her iki cinsiyetten, 2-5 yaş aralı̆ında toplam 45 adet Saanen ırkı keçi oluşturdu. Çalışma grubunda 35, kontrol grubunda ise 10 hayvan değerlendirildi. Bütün hayvanlardan alınan kanlarda tam kan sayımları yapıldı. Ayrıca toplanan serumlarda interlökin 6 , interlökin 10, serum amiloid A, haptoglobin, fibrinojen ve hepsidin değerleri ölçüldü. Sonuç olarak gruplar arası interlökin $6(p<0.01)$, interlökin $10(p<0.01)$ serum amiloid A $(p<0.001)$, haptoglobin $(p<0.001)$, fibrinojen $(p<0.05)$ ve hepsidin $(p<0.05)$ değerlerindeki farklar istatistiksel açıdan önemli bulunarak paratüberkülozun teşhisini desteklemede belirtilen parametrelerin kullanılabileceği kanaatine varıldı.

\begin{tabular}{ll}
\hline Anahtar Kelimeler: Akut faz protein, Sitokin, Hepsidin, Paratüberkülozis, Saanen keçi. \\
\hline${ }^{*}$ Corresponding author : Şima ŞAHINNDURAN & e-mail : sahinduran@mehmetakif.edu.tr \\
Geliş tarihi / Received : $17.09 . .2021$ & Kabul tarihi / Accepted: 08.11.2021
\end{tabular}

\section{Introduction}

Paratuberculosis is a disease caused by bacteria formerly known as Mycobacterium paratuberculosis. With the molecular characterization developed in the nineties, the causative agent was classified as a subspecies of Mycobacterium avium and $M$. avium subsp. 
paratuberculosis (Map) has been reported (Harris and Barletta, 2001). The disease, which occurs sporadically in temperate climates and sporadically in the tropics, has spread as a result of the importation of animals from regions where it is endemic. It is difficult to find sufficient data on the geographical distribution of goat paratuberculosis, as statistics on goat diseases are often reported together with sheep diseases by governments and international agencies. Goats can also become infected as a result of ingestion of the agent at an early age. Goats often show no signs of chronic watery diarrhea unless they are in the last stage of the disease. However, if diarrhea is observed, it has been reported that it may be caused by parasitic factors as well as paratuberculosis. It has been stated that there may be soft stools such as dog feces from time to time, but pellet defecation generally continues (Radostits et al., 2007).

The secretion of cytokines, which are proinflammatory substances, from damaged tissues in response to tissue damage is called the acute phase response, and it can be considered as an early warning system that informs the state of the body (Gruys et al., 2005; Cray et al., 2009; Ceciliani et al., 2012). The aim of the acute phase response is to prevent further damage to an organ, limit the reproduction of the infective organism, remove harmful molecules, and activate the repair processes necessary for the organ to return to normal function (Hirvonen, 2000). Cytokines are first released by macrophages and monocytes in the damaged tissue, go to various tissues and organs through the circulation, cause release from other tissues and organs, and a systemic cytokine release begins (Eckersall, 2000). With the effect of systemic cytokine release, the circulating density of some plasma proteins, generally known as acute phase proteins (AFPs), is increased to support changes from hepatocytes (Eckersall, 2000, Hirvonen, 2000).

Interleukin-6 (IL-6) is a pleiotropic cytokine involved in regulation of acute phase response, cell growth and differentiation as well as metabolic processes (Neurath and Finotto, 2011). Interleukin 10 (IL-10) was first defined as a "cytokine synthesis inhibitory factor" and it was reported to suppress the production of Th1 cytokines such as IL-2 and IFN- $\gamma$ by acting on antigen-presenting cells (De Silva et al., 2011).

Serum Amyloid A (SAA) as acute phase protein is thought to affect high-density lipoproteincholesterol transport. It stimulates inflammatory cells in tissues, prevents leukocytes from losing their structure as a result of oxidation, and manages the immune response. Haptoglobulin $(\mathrm{Hp})$ is not found in healthy bovine serum. This protein has numerous reported functions, but its primary function is to prevent iron loss by forming highly stable complexes with free hemoglobin in the blood (Ceron et al., 2005). Thus, it has been stated that $\mathrm{Hp}$ has a bacteriostatic effect by limiting the availability of iron required for bacterial growth (Ceron et al., 2005; Ametaj et al., 2011). Fibrinogen has functions such as homeostasis, providing a substrate for fibrin formation, and providing an interface for the migration of inflammatory cells to the inflammatory region, tissue-repairing, clotforming, and C3 complement-forming (Gruys et al., 2005).

Hepcidin, discovered in recent years, is a peptide hormone with multiple functions. In the first reported studies, hepcidin was named as an antimicrobial in peptide structure in human blood and urine (Park et al., 2001), but in later studies it was reported that it was a type II acute phase reactant and played a role as a regulator in iron metabolism (Nicolas et al., 2002; Laftah et al., 2004). Studies in humans have reported that hepcidin is mainly released from hepatocytes, but it is also produced by kidney, pancreatic beta cells, adipose tissue and heart tissue (Merle et al., 2007; Kemna et al., 2008; Kulaksiz et al., 2008). It has also been detected in various body fluids, such as urine, bile, pleural and cerebrospinal fluids (Kemna et al., 2008; Arnold et al., 2010).

The aim of the study was to investigate the effect of Mycobacterium avium subsp paratuberculosis on blood parameters, some acute phase proteins, cytokines and hepcidin in naturally infected goats with paratuberculosis. 


\section{Materials and Methods}

This research was carried out based on the permission of Mehmet Akif Ersoy University Experimental Animals Local Ethics Committee, dated 09.09.2015 and numbered 143/2015.

Saanen goats bred in farms in different provinces constituted the research material. In this study, blood samples were collected from the animals in the study group, considering the following clinical signs and criteria.

\section{Clinical Symptoms Desired}

- Diarrhea $( \pm)$

- Progressive weight loss

- Yield loss

- No other obvious symptoms on clinical examination despite the above data.

There were complaints such as weight loss and chronic diarrhea problems in goat herds. Despite treatment, there was no improvement. It has been confirmed that flocks have not been previously vaccinated against paratuberculosis. A total of 750 blood samples were collected according to the criteria mentioned above, and 610 of them were female and 140 male Saanen goats. 105 animals were found to be seropositive for paratuberculosis $(14 \%)$ and 35 of them constituted the study group. 29 of the animals were female and 6 were male and their ages varied between 2-5 years. The control group consisted of 10 healthy animals negative for paratuberculosis. The sexes of the animals in this group were 7 females and 3 males, and their ages were between 2-5 years old.

Venous blood samples from all goats were taken from vena jugularis into negative pressure tubes with the help of Vacutainer ${ }^{\circledR}$ holder with 21 gauge needle. Plastic tubes with K3-EDTA $(2.5 \mathrm{ml})$ were used for hemogram samples and silicone-based plastic tubes $(5 \mathrm{ml})$ with clot activator for serum samples (BD Vacutainer $\left.{ }^{\circledR}\right)$. Collected blood samples were centrifuged at $4000 \mathrm{rpm} / 5 \mathrm{~min}$ and blood serums were extracted. The obtained sera were divided into tubes and stored at $-20^{\circ} \mathrm{C}$ until processed. The collected 750 blood serums were screened for paratuberculosis with the ELISA test (IDEXX MAP Ab ELISA Test, America).
Samples were duplicated to increase the reliability of the test. As a result of the ELISA test, 105 of 750 blood samples were positive for paratuberculosis $(14 \%)$. In the interpretation of the results, the percentage of sample/positivity (s/p \%) was calculated for each sample. According to this evaluation, $\mathrm{s} / \mathrm{p}$ percentage $\leq 45 \%$ was evaluated as negative, $>45 \%-<55 \%$ as suspicious, and $\geq 55 \%$ as positive. Of the 105 positive samples, 30 serum samples with the highest percentage of positivity were included in the study. The $\mathrm{s} / \mathrm{p}$ values of the samples in the study ranged between 65.98-171.24. To form the control group, 10 animals were selected from other herds that were healthy as a result of clinical examinations. Serum samples collected from these animals, like the samples in the study group, were examined for paratuberculosis by ELISA method and the $\mathrm{s} / \mathrm{p}$ percentages were determined as $0.00-0.38$.

Thirty-five animals in the study group (naturally paratuberculous animals) and 10 animals in the control group (healthy and paratuberculosisnegative animals) were evaluated. Complete blood counts (Abacus Junior Vet Hematology Analyzer ${ }^{\circledR}$, Diatron, Hungary) were taken from all animals with EDTA tubes. In addition, serum samples collected from these animals, haptoglobin, serum amyloid A, fibrinogen, interleukin 6, interleukin 10 and hepcidin values were measured in the collected sera. Finally, haptoglobin, serum amyloid A, fibrinogen, interleukin 6 , interleukin 10 and hepcidin values of healthy and paratuberculosis animals were compared.

Interleukin 6, interleukin 10, serum amyloid A, haptoglobin, fibrinogen and hepcidin values in blood serum were measured by ELISA (EnzymeLinked Immunosorbent Assay) method. In the research, goat-specific 96 IL-6 (Catalog no: MBS734666), IL-10 (Catalog no: MBS265401), Fb (Catalog no: MBS735156), of MyBioSource ${ }^{\circledR}$ (MyBioSource Inc., Southern California, San Diego/USA), Hp (Catalog no: MBS280796), SAA (Catalog no: MBS031629) and Hepcidin (Catalog no: MBS044535) ELISA test kits were used. Serum samples taken in the study were evaluated with the kits of MyBioSource ${ }^{\circledR}$. The kits were 
stored in accordance with the instructions for use on them and then worked again according to the instructions. Microsoft Office ${ }^{\circledR}$ Excel program was used for calculations after ELISA measurements. The data obtained at the end of the procedure were calculated with the calculation method in the kit, curve graphics were created and the samples were grouped and calculated in accordance with this slope.

\section{Statistical analysis}

Statistical analysis was performed with the SPSS 19 program (IBM Corp. Released 2010. IBM SPSS Statistics for Windows, Version 19.0. Armonk, NY: IBM Corp). Paired T Test was used while evaluating the obtained hemogram and ELISA results. In the comparison between the groups, values less than $\mathrm{p}<0.05$ were found to be statistically significant and included in the study.

\section{Results}

Thirty serum samples with the highest positivity percentage out of 105 samples with positive paratuberculosis disease were included in the study. The $\mathrm{s} / \mathrm{p}$ values of the samples in the study ranged between 65.98-171.24 (Table 1).

To form the control group, 10 animals were selected from other herds that were healthy as a result of clinical examinations. Serum samples collected from these animals, like the samples in the study group, were examined for paratuberculosis by ELISA method and the $\mathrm{s} / \mathrm{p}$ percentages were determined as 0.00-0.38 (Table 2).

When the hematological parameters of the control and study groups were evaluated, the difference between erythrocyte $(\mathrm{p}<0.05)$, hemoglobin $(\mathrm{p}<0.05), \quad$ hematocrit $(\mathrm{p}<0.05), \quad$ monocytes $(p<0.05)$ and leukocyte $(p<0.01)$ values was found to be significant. The difference between eosinophil and platelet values was not significant (Table 3).
Table 1. Sample/positive values of paratuberculous $(+)$ animals.

\begin{tabular}{|c|c|}
\hline Sample No. & S/P Values \\
\hline 1 & 145.21 \\
\hline 2 & 123.32 \\
\hline 3 & 114.44 \\
\hline 4 & 130.89 \\
\hline 5 & 65.98 \\
\hline 6 & 125.55 \\
\hline 7 & 167.01 \\
\hline 8 & 102.26 \\
\hline 9 & 170.79 \\
\hline 10 & 127.35 \\
\hline 11 & 171.24 \\
\hline 12 & 115.67 \\
\hline 13 & 148.99 \\
\hline 14 & 136.65 \\
\hline 15 & 129.25 \\
\hline 16 & 114.52 \\
\hline 17 & 142.66 \\
\hline 18 & 161.42 \\
\hline 19 & 94.28 \\
\hline 20 & 123.82 \\
\hline 21 & 144.63 \\
\hline 22 & 108.02 \\
\hline 23 & 141.35 \\
\hline 24 & 87.45 \\
\hline 25 & 137.12 \\
\hline 26 & 90.09 \\
\hline 27 & 134.17 \\
\hline 28 & 105.39 \\
\hline 29 & 96.75 \\
\hline 30 & 132.09 \\
\hline 31 & 132.43 \\
\hline 32 & 107.54 \\
\hline 33 & 99.12 \\
\hline 34 & 98.54 \\
\hline 35 & 83.32 \\
\hline
\end{tabular}

While the difference between hepcidin and fibrinogen values of the control and study groups was found to be statistically insignificant ( $p>0.05$ ), the difference between cytokine IL-6 and IL-10 values was found to be moderately significant $(\mathrm{p}<0.01)$. According to this table, the highest difference was found between the acute phase 
proteins haptoglobin and serum amyloid A values in animals in the control and study groups $(\mathrm{p}<0.001)$ (Table 4).

Table 2. Sample/positive values of paratuberculosis (-) animals.

\begin{tabular}{cc}
\hline Sample No. & S/P Values \\
\hline 1 & 0.19 \\
2 & 0.07 \\
3 & 0.15 \\
4 & 0.07 \\
5 & 0.15 \\
6 & 0.08 \\
7 & 0.15 \\
8 & 0.38 \\
9 & 0.0 \\
10 & 0.3 \\
\hline
\end{tabular}

Johne's disease or paratuberculosis causes chronic inflammation in the gastrointestinal tract in ruminants and is caused by Mycobacterium avium subsp. paratuberculosis. The disease causes significant economic losses worldwide, with low productivity, sustained weight loss and eventual death in ruminants (Chiodini et al., 1984). All sick animals in the study had a history of progressive weight loss and poor conditioning. The gold standard for diagnosis in eradicating paratuberculosis disease is based on detecting infected animals and preventing the spread of the disease. Undoubtedly, an effective diagnosis and a successful control program are required rather than an expensive treatment. Therefore, additional biochemical markers are essential for the control of paratuberculosis disease.

\section{Discussion}

Table 3. Values of some hematological parameters in the control and study groups.

\begin{tabular}{cccc}
\hline Parameters & $\begin{array}{c}\text { Control Group } \\
(\mathbf{n}=\mathbf{1 0}) \\
(\mathbf{O r t .} \pm \mathbf{S D})\end{array}$ & $\begin{array}{c}\text { Study Group } \\
(\mathbf{n}=\mathbf{3 5}) \\
(\mathbf{O r t .} \pm \mathbf{S D})\end{array}$ & P Values \\
\hline Leukocyte (X109/L) & $7.55 \pm 0.86$ & $15.98 \pm 2.42$ & $<0.01^{* *}$ \\
Neutrophil (X109/L) & $4.54 \pm 1.55$ & $8.45 \pm 1.36$ & $>0.05$ \\
Lymphocyte (X109/L) & $4.72 \pm 0.90$ & $4.42 \pm 0.68$ & $>0.05$ \\
Monocyte (X109/L) & $0.13 \pm 0.07$ & $0.15 \pm 0.10$ & $<0.05^{*}$ \\
Eosinophil (X10 $/ \mathrm{L})$ & $0.14 \pm 0.10$ & $0.19 \pm 0.14$ & $>0.05$ \\
Erythrocyte (X1012/L) & $10.26 \pm 0.90$ & $6.57 \pm 0.56$ & $<0.05^{*}$ \\
Hemoglobin (g/dl) & $9.46 \pm 0.94$ & $6.70 \pm 0.51$ & $<0.05^{*}$ \\
Hematocrit (\%) & $31.70 \pm 2.11$ & $30.17 \pm 3.55$ & $<0.05^{*}$ \\
Platelets (X10 $/ \mathrm{L})$ & $406.60 \pm 24.55$ & $402.77 \pm 42.94$ & $>0.05$
\end{tabular}

*lowly significant, ${ }^{* *}$ moderately significant, $\mathrm{p}>0.05$ statistically insignificant.

Senturk et al. (Senturk et al., 2009) found that erythrocyte, hemoglobin and hematocrit values in cows with paratuberculosis were lower than healthy cows in the control group. However, they stated that there was no difference in the number of leukocytes, neutrophils, lymphocytes, monocytes, eosinophils and platelets. In the study, erythrocyte, hemoglobin and hematocrit values in goats with paratuberculosis were decreased compared to the values of healthy goats, and the difference was found to be statistically significant $(p<0.05)$, and the results were found to be in parallel with the results of the study. The hematocrit value of the study group was lower than the control group, but within normal limits. Although the result of hematocrit value is within normal limits, the difference is statistically significant, it can be concluded that the appetite 
does not decrease in sick goats and dehydration is hidden by continuing fluid consumption. However, according to the results obtained, it was observed that the number of leukocytes $(p<0.01)$ and monocytes $(p<0.05)$ increased in the animals in the study group compared to the animals in the control group and were found to be statistically significant. Lybeck et al. (Lybeck et al., 2011) showed that anemia occurred in naturally infected goats with paratuberculosis. In the current study, decreases in erythrocyte, hemoglobin and hematocrit values also indicate anemia and show parallelism with other studies. The increase in the number of monocytes in hematological results is thought to be due to the chronic course of the disease.

Table 4. Values of IL-6, IL-10, SAA, Hp, Fb and Hepcidin in the control and study groups.

\begin{tabular}{lccc}
\hline \multicolumn{1}{c}{ Parameters } & $\begin{array}{c}\text { Control Group } \\
(\mathbf{n = 1 0 )}\end{array}$ & $\begin{array}{c}\text { Study Group } \\
(\mathbf{n}=\mathbf{3 5})\end{array}$ & P Values \\
\hline Interleukin-6 $(\mathrm{pg} / \mathrm{ml})$ & $56.56 \pm 10.39$ & $293.66 \pm 35.07$ & $<0.01^{* *}$ \\
Interleukin-10 $(\mathrm{pg} / \mathrm{ml})$ & $9.02 \pm 1.70$ & $43.81 \pm 4.40$ & $<0.01^{* *}$ \\
Serum Amiloid A $(\mu \mathrm{g} / \mathrm{ml})$ & $5.67 \pm 1.19$ & $422.88 \pm 118.14$ & $<0.001^{* * *}$ \\
Haptoglobin $(\mathrm{ng} / \mathrm{ml})$ & $0.01 \pm 0.00$ & $1.95 \pm 0.64$ & $<0.001^{* * *}$ \\
Fibrinogen $(\mathrm{ng} / \mathrm{ml})$ & $3.11 \pm 0.54$ & $7.97 \pm 1.24$ & $<0.05^{*}$ \\
Hepcidin $(\mathrm{ng} / \mathrm{ml})$ & $3.67 \pm 0.58$ & $52.03 \pm 6.93$ & $<0.05^{*}$ \\
\hline
\end{tabular}

*Low important, $* *$ moderately important, $* * *$ highly important

Interleukin 6 is a proinflammatory cytokine. It is produced by Th2 cells, acts as a mediator in the formation of the acute phase response and also accelerates the infiltration of inflammatory cells (O'Garra and Murphy, 2009). It has been reported that IL-6 induces hepcidin production during immune activation (Nemeth et al., 2004). In the study, the IL-6 level in the blood serum of the goats in the control group was $56.56 \pm 10.39$ $(\mathrm{pg} / \mathrm{ml})$ and $293.66 \pm 35.07(\mathrm{pg} / \mathrm{ml})$ in the study group. In the statistical evaluation, the difference between these two groups was found to be significant $(p<0.01)$. The results obtained were consistent with the results of previous studies. In addition, as mentioned before, the increase in hepcidin value showed parallelism with the increase in IL- 6 in the animals in the experimental group. IL-10 produced by monocytes and macrophages is a cytokine that contributes to the regulation of the immune system and is an important balancer between Th1 and Th2 (O'Garra and Murphy, 2009). In previous studies, high levels of IL-10 were detected in goats and sheep with paratuberculosis (Lybeck et al., 2013). In this study, the level of interleukin-10 was found to be $9.02 \pm 1.70(\mathrm{pg} / \mathrm{ml})$ in goats in the control group and $43.81 \pm 4.40(\mathrm{pg} / \mathrm{ml})$ in goats with paratuberculosis. In the statistical evaluation made according to this, it was determined that the difference between IL-10 levels of goats with paratuberculosis and healthy goats was significant $(\mathrm{p}<0.01)$.

Although the determination of AFPs in goat medicine has been reported to be clinically valuable, there is a lack of information in the veterinary field on this subject. Acute phase proteins are sensitive biomarkers, but their specificity is low against various infectious agents. It is also used in the diagnosis, prognosis and health status screening of animals (Murata et al., 2004). Circulating haptoglobin levels in healthy ruminants are very low and insignificant, but increase 100-fold in animals with compromised immune systems (Conner et al., 1998). Gonzalez et al. (2008) found the highest increase in serum haptoglobin level in infectious conditions in a study they conducted. According to this researcher, haptoglobin and serum amyloid $\mathrm{A}$ proteins can be used as an indicator of inflammation in goats. In previous studies on goats, haptoglobin levels were found to be increased in lactating goats (Heller and Johns, 2015), goats with pregnancy toxemia (Albay et al., 2014), turpentine injected goats (Gonzalez et al., 2008), goats with Corynebacterium 
pseudotuberculosis (Jeber et al., 2016) and in many other studies. In this study, a statistically significant difference was found in the mean serum haptoglobin and serum amyloid A values of the animals in the study group compared to the values of the animals in the control group $(p<0.001)$. These results were in agreement with the results of other researchers. It has been reported that the level of fibrinogen, which is one of the positive acute phase proteins, increases up to 10 times in cases of inflammation (Eckersall, 2000). Kaneko et al. (2008) found that the blood fibrinogen value in goats varied between $1-4 \mathrm{ng} / \mathrm{ml}$, but this value increased to $9.12 \mathrm{ng} / \mathrm{ml}$ after infection. El-Deeb (2013) reported a lower fibrinogen value $(3.84 \pm 0.21 \mathrm{ng} / \mathrm{ml})$ in goats with gangrenous mastitis. Similar fibrinogen values $(9.6 \mathrm{ng} / \mathrm{ml})$ Gonzalez et al. (2008) has also been reported by Experimentally, the fibrinogen level was found to be $9.12 \mathrm{ng} / \mathrm{ml}$ in goats with mastitis with Staphylococcus aureus (Fasulkov et al., 2014).

In this study, the mean fibrinogen value in goats in the control group was determined as $3.11 \pm 0.54$ $\mathrm{ng} / \mathrm{ml}$, which was consistent with the results of previous studies (Hajimohammadi et al., 2013; Fasulkov et al., 2014). The mean fibrinogen level in the animals in the study group was determined as $7.97 \pm 1.24 \mathrm{ng} / \mathrm{ml}$, and the statistical difference was found to be significant compared to the control group $\quad(\mathrm{p}<0.05)$.

Hepcidin, discovered in recent years, is a peptide hormone with multiple functions. Hepcidin was named as an antimicrobial in the first reported studies (Park et al., 2001), but it was reported that it was a type II acute phase reactant and played a role as a regulator in iron metabolism in later studies (Laftah et al., 2004). Kali et al. (2015) reported that hepcidin is triggered by IL-6 during inflammation and can be used as an important marker in sepsis and inflammatory reactions. Although studies on hepcidin in human medicine have increased in recent years, there have not been many studies in veterinary medicine. In this study, hepcidin value was investigated for the first time in goats with paratuberculosis. As a result of the study, hepcidin value was found as $3.67 \pm 0.58$ $(\mathrm{ng} / \mathrm{ml})$ in healthy goats, while it was determined as $52.03 \pm 6.93(\mathrm{~g} / \mathrm{ml})$ in goats with paratuberculosis. In this study, the highest levels of serum amyloid $\mathrm{A}$ and haptoglobin, which are acute phase proteins, the lowest levels of fibrinogen and hepcidin, and a moderate increase in cytokines levels were determined.

As a result, it was determined that SAA and haptoglobin the highest, IL-6 and IL-10 parameters moderate, and fibrinogen and hepcidin were the least increased parameters in goat paratuberculosis disease.

\section{Acknowledgments}

This study was supported by Mehmet Akif Ersoy University Scientific Research Projects Commission (Project No: 0259-DR-15).

\section{References}

Albay, M.K., Karakurum, M.C., Sahinduran, S., Sezer, K., Yildiz, R., Buyukoglu, T., 2014. Selected serum biochemical parameters and acute phase protein levels in a herd of Saanen goats showing signs of pregnancy toxaemia. Veterinary Medicine JournalCzech 59(7), 336-342.

Ametaj, B.N., Hosseini, A., Odhiambo, J.F., Iqbal, S., Sharma, S., Deng, Q., Lam, T.H., Farooq, U., Zebeli, Q., Dunn, S.M., 2011. Application of acute phase proteins for monitoring inflammatory states in cattle. Ed: VEAS F, Acute phase proteins as early nonspecific biomarkers of human and veterinary diseases, Croatia 299-354.

Arnold, J., Sangwaiya, A., Manglam, V., Geoghegan, F., Thursz, M., Busbridge, M., 2010. Presence of hepcidin-25 in biological fluids: bile, ascitic and pleural fluids. World Jounal of Gastroenterology 16, 2129-2133.

Ceciliani, F., Ceron, J.J., Eckersall, P.D., Sauerwein, H., 2012. Acute phase proteins in ruminants. Journal of Proteomics 75, 4207-4231.

Ceron, J.J., Eckersall, P.D., Martinez-Subiela, S., 2005. Acute phase proteins in dogs and cats: current knowledge and future perspectives. Veterinary Clinical Pathology 34(2), 85-99.

Chiodini, R.J., Van Kruiningen, H.J., Merkal, R.S., 1984. Ruminant paratuberculosis (Johne's disease): the current status and future prospects. The Cornell Veterinarian 74, 218-262.

Conner, J.G., Eckersall, P.D., Wiseman, A., Aitchison, T.C., Douglas, T.A. 1998. Bovine acute phase response following turpentine injection. Research in Veterinary Science 44, 82-88. 
Cray, C., Zaias, J., Altman, N.H., 2009. Acute phase response in animals: A review. Comparative Medicine 59(6), 517-526.

De Silva, K., Begg, D., Whittington, R., 2011. The interleukin 10 response in ovine Johne's disease. Veterinary Immunology and Immunopathology 139, 10-16.

Eckersall, P.D., 2000. Recent advances and future prospects for the use of acute phase proteins as markers of disease in animals. Revue de Médecine VétérinaireToulouse., 151(7), 577-584.

E1-Deeb, W.M., 2013. Clinicobiochemical investigations of gangrenous mastitis in does: immunological responses and oxidative stress biomarkers. Journal of Zhejiang University. Science. B 14, 33-39.

Fasulkov, I., Karadaev, M., Vasilev, N., Urumova, V., Mircheva, T., 2014. Determination of plasma fibrinogen and haptoglobin, hematological and blood biochemical changes in Bulgarian local goats with experimentally induced Staphylococcus aureus mastitis. Turkish Journal of Veterinary \& Animal Sciences 38, 439-444.

Gonzalez, F.H.D., Tacles, F., Martinez-Subiela, S., Tvarijonaviciute, A., Soler, L., Ceron, J.J., 2008. Acute phase protein response in goats. J Vet Diagn Invest., 20, 580-584.

Gruys, E., Toussaint. M.J.M., Niewold, T.A., Koopmans, S.J., 2005. Acute phase reaction and acute phase proteins. Journal of Zhejiang University. Science A 6 (11), 1045-1056.

Hajimohammadi, A., Nazifi, S., Ansari-Lari, M., Khoshmanzar, M.R., Bigdeli, S.M., 2013. Identifying relationships among acute phase proteins (haptoglobin, serum amyloid A, fibrinogen, ceruloplasmin) and clinical findings in dairy calf diarrhea. Comparative Clinical Pathology 22(2), 227 232.

Harris, N.B., Barletta, R.G., 2001. Mycobacterium avium subsp. paratuberculosis in veterinary medicine. Clinical Microbiology Reviews 14(3), 489-512.

Heller, M.C., Johns, J.L., 2015. Acute phase proteins in healthy goats: establishment of reference intervals. Journal of Veterinary Diagnostic Investigation 27(2), 177-181.

Hirvonen, J., 2000. Hirvonen's thesis on acute phase response in dairy cattle, Ed: Pyörälä S, University of Helsinki Faculty of Veterinary Medicine Publications, Helsinki 7-67.

Jeber, Z.K.H., Mohdjin, Z., Jesse, F.F., Saharee, A.A., Sabri, J., Yusoff, R., Wahid, H., 2016. Influence of Corynebacterium pseudotuberculosis infection on level of acute phase proteins in goats. BMC Veterinary Research., 12(48), 1-5.
Kali, A., Charles, M.V.P., Seetharam, R.S.K., 2015. Hepcidin-A novel biomarker with changing trends. Pharmacognosy Reviews 9(17), 35-40.

Kaneko, J.J., Harvey, J.W., Bruss, M.L., 2008. Clinical Biochemistry of Domestic Animals, 6th edition. Saunders, Philadelphia, USA.

Kemna, E.H., Tjalsma, H., Willems, H.L., Swinkels, D.W., 2008. Hepcidin: from discovery to differential diagnosis. Haematologica 93, 90-97.

Kulaksiz, H., Fein, E., Redecker, P., Stremmel, W., Adler, G., Cetin, Y., 2008. Pancreatic beta-cells express hepcidin, an iron-uptake regulatory peptide. Journal of Endocrinology 197, 241-249.

Laftah, A.H., Ramesh, B., Simpson, R.J., Solanky N, Bahram S, Schumann K, Debnam ES, Sari SKS (2004): Effect of hepcidin on intestinal iron absorption in mice. Blood 103, 3940-3944.

Lybeck, K.R., Storset, A.K., Djønne, B., Valheim, M., Olsen, I., 2011. Faecal shedding detected earlier than immune responses in goats naturally infected with Mycobacterium avium subsp. paratuberculosis. Research in Veterinary Science 91, 32-39.

Lybeck, K.R., Løvoll, M., Johansen, T.B., Olsen, I., Storset, A.K., Valheim, M., 2013. Intestinal strictures, fibrous adhesions and high local interleukin-10 levels in goats infected naturally with Mycobacterium avium subsp. paratuberculosis. Journal of Comparative Pathology 148, 157-172.

Merle, U., Fein, E., Gehrke, S.G., Stremmel, W., Kulaksiz, H., 2007. The iron regulatory peptide hepcidin is expressed in the heart and regulated by hypoxia and inflammation. Endocrinology 148, 26632668.

Murata, H., Shimada, N., Yoshioka, M., 2004. Current research on acute phase proteins in veterinary diagnosis: an overview. Veterinary Journal 168, 28-40.

Nemeth, E., Rivera, S., Gabayan, V., Keller. C., Taudorf, S., Pedersen, B.K., Ganz, T., 2004. IL-6 mediates hypoferremia of inflammation by inducing the synthesis of the iron regulatory hormone hepcidin. Journal of Clinical Investigation 113(9), 1271-1276.

Neurath, M.F., Finotto, S., 2011. IL-6 signaling in autoimmunity, chronic inflammation and inflammation-associated cancer. Cytokine and Growth Factor Reviews 22, 83-89.

Nicolas, G., Viatte, L., Bennoun, M., Kahn, A., Vaulont, S., 2002. Hepcidin, a new iron regulatory peptide. Blood Cells, Molecules and Diseases 29, 327335.

O'Garra, A., Murphy, K.M., 2009. From IL-10 to IL12: how pathogens and their products stimulate APCs to induce $\mathrm{T}(\mathrm{H}) 1$ development. Nature Immunology 10 , 929-932. 
Park, C.H., Valore, E.V., Waring, A.J., Ganz, T., 2001. Hepcidin, a urinary antimicrobial peptide synthesized in the liver. Journal of Biological Chemistry 276, 7806-7810.

Radostits, O.M., Gay, C.C., Hinchcliff, K.W., Constable, P.D., 2007. Veterinary Medicine. A textbook of the diseases of cattle, horse, sheep, pigs and goats, 10th Ed, Saunders Elsevier, Edinburgh.

Senturk, S., Metcitoglu, Z., Ulgen, M., Borum, E., Temizel, E., Kasap, S., 2009. Evaluation of serum iron and iron binding capacity in cows with paratuberculosis. Tierarztliche Praxis Ausgabe Grobtiere Nutztiere 37(6), 375-378. 